\title{
Visitor profiling for cable car mountain destinations as a basis for protected area management: a case study of the summer season in the Tatra Mountains at Kasprowy Wierch (Poland) and Skalnaté Pleso (Slovakia)
}

\author{
Joanna Hibner, Karolina Taczanowska, Antoni Zięba, Christiane Brandenburg, Andreas Muhar \& Jarosław \\ Balon
}

Keywords: protected area, tourism, visitor profiling, segmentation, social marketing, cable car, Tatra National Park, Carpathian Mountains

\section{Abstract}

Protected areas play a crucial role in the conservation of vulnerable mountain ecosystems, but at the same time they may serve as tourist destinations and attract large numbers of visitors. Areas located in close proximity to cable cars belong to some of the most challenging sites for mountain protected area management. This study focuses on two cable car areas: Kasprowy Wierch (Tatra National Park, Poland) and Skalnaté Pleso (Tatra National Park, Slovakia). Both sites belong to the most heavilyused leisure destinations in the Tatra Mountains. The study focused on the summer, snow-free tourist peak-season, for which there is an ongoing discussion concerning the development of cable car services. In 2014 and 2015, on-site interviews were conducted in the two study areas $(n=3304)$. In order to better understand visitors' needs and goals, visitor profiling using K-means clustering was performed. Four distinct segments based on visitor motivations were identified: nature oriented (32\%), family/friends \& well-being oriented (23\%), sports oriented (14\%), and a mixed segment with multiple motivations (31\%). The results show that two tourist segments were not particularly interested in nature experience, although they visited protected areas. A significant relationship between motivational segments and trip characteristics was identified. The visitor segments defined can be used practically in the management of cable car destinations located within protected areas.
Profile

Protected area

Tatra National Park

Mountain range

Carpathians

Country

\section{Slovakia \& Poland}

\section{Introduction}

Protected areas (PAs) play a crucial role in the conservation of vulnerable mountain ecosystems (IUCN 2016). Depending on the nature conservation regime, they may also have social functions, such as providing space for recreation, research and educational purposes (Dudley 2008). Mountain PAs are usually attractive tourism destinations. Management plans of such areas foster the development of environmentally responsible tourism to minimize the impact on the natural environment. Ecotourism and conservation tourism are desirable directions in the development of tourism in PAs (Newsome 2002; Buckley 2010; Leung et al. 2015; Plummer \& Fennel 2009).

The pressure from the tourism industry, especially in popular PA destinations, is growing, and some sites are gradually becoming mass tourist destinations, rather than contemplative natural oases. It is a challenge for PA managers to satisfy the needs and expectations of visitors, local communities and entrepreneurs without creating extensive impacts on the natural environment (Eagles et al. 2002; Kohl \& Pekny 2011; Gulič 2014). One challenging activity within PAs is cable car operation. Originally, many cable car infrastructures were dedicated to winter sports. Nowadays, they extend their services to other seasons and address a wider range of recreational activities (Needham et al. 2004; Needham et al. 2010; Gundersenet al. 2016). Tourist services are not limited to riding cable cars or hiking in their immediate vicinity. More and more destinations offer an extensive repertoire of activities, such as downhill mountain biking, paragliding, picnicking, or amusement parks on the slopes (Needham et al. 2004; Muhar et al. 2007). Increased consumer demands create a need for tourist product differentiation and foster innovation in the visitor service sector, rather than further cable car infrastructure development (Mayer 2009).

Many studies demonstrate a wide variety of visitor motivations and expectations regarding outdoor recreation (Palacio \& McCool 1997; Manning 2011; Smith et al. 2014). Comprehensive knowledge about visitors' motivations is important from the point of view of the management of PAs (Cessford \& Muhar 2003; Konu \& Kajala 2012). Tourist services dedicated to particular visitor profiles are believed to be more effective than those without a specified target group (Moscardo et al. 2001). The aim of segmentation is to divide visitors into homogeneous segments, which should be as similar within each cluster as possible while simultaneously the differences between segments should be very stark (Haley 1968; Van Marwijk \& Taczanowska 2006; Dolnicar \& Grün 2008; Konu 


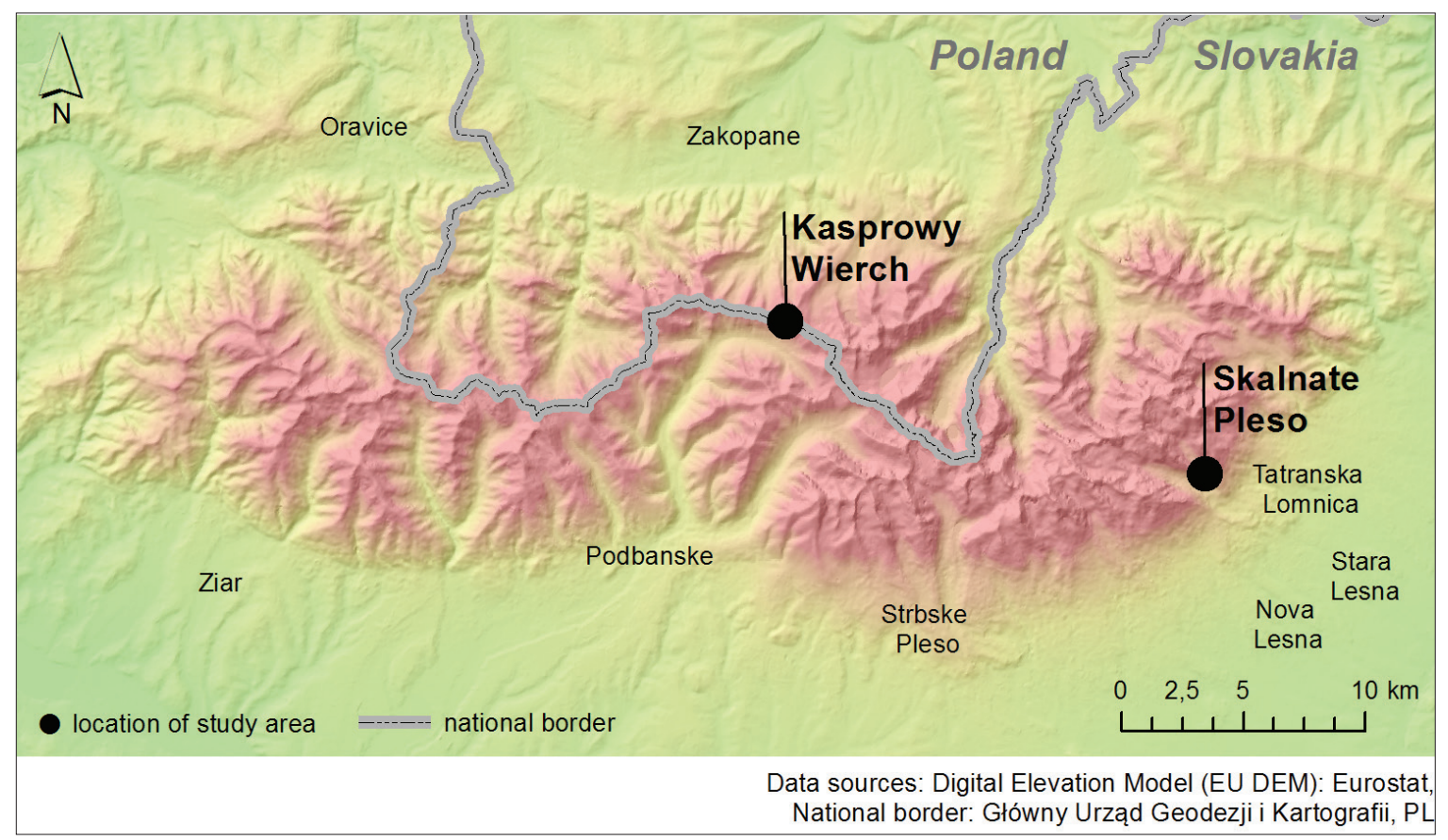

Figure 1 - Location of study areas in the Tatra Mountains.

\& Kajala 2012). There is a wide range of typologies based on motivational factors in outdoor recreation studies (Bieger \& Laesser 2002; Sterl et al. 2006; Park \& Yoon 2009; Needham et al. 2010; Konu \& Kajala 2012; Rid et al. 2014). Also very popular are typologies based on benefits sought, visitor attitudes or cultural values (Kastenholz et al. 1999; Galloway 2002; Frochot 2005; Li et al. 2006; Molera \& Albaladejo 2007). Some authors segment by using combined variables, including motivational or sociodemographic factors, or other psychographic factors (Farías Torbidoni et al. 2005; Taczanowska et al. 2006; Smith et al. 2014). Typologies based on crowding perception (Arnberger \& Haider 2005) or type of activity (Burns \& Graefe 2002) are also common in tourism literature. Modern solutions such as fuzzy segmentation are also found (D’Urso et al. 2016). In theoretical studies, authors focus mainly on motivational factors or visitor attitudes (Przecławski 1996; Ankre 2005; Stankey 1973), while other well-known theoretical typologies are based on the degree of institutionalization of the tourist, e.g. drifter, explorer, individual mass and organized mass tourist types (Cohen 1979).

The main purposes of this study were to profile summer visitors to two cable car areas based on their motivations, and to identify relationships between motivational segments, visitors' behaviour and their sociodemographic characteristics. An additional aim was to compare visitor segment distribution between two cable car areas - Kasprowy Wierch (KW) and Skalnaté Pleso (SP) - located in two PAs that implement different management strategies.

\section{Methods}

\section{Study areas}

Both study areas are located in the Tatra Mountains, which form the highest part of the Western Carpathians. The Tatra Mountains are a trans-boundary mountain range across the border of Poland and Slovakia (Figure 1). The Tatras are protected by two National Parks: Tatrzański Park Narodowy (TPN) in Poland and Tatranskỳ Národnỳ Park (TANAP) in Slovakia. Both National Parks attract large numbers of visitors. According to annual statistics, about 3 million tourists visit TPN each year (TPN 2016). TANAP conducts manual counting of visitors only on one day per year during the summer season, thus there are no annual data available for the number of visitors in this PA. Furthermore, TANAP $\left(738 \mathrm{~km}^{2}\right)$ covers an area that is more than three times the size of TPN $\left(212 \mathrm{~km}^{2}\right)$ (Švajda \& Šturcel 2005; Švajda 2009; Streberová \& Jusková 2015).

This study focuses on two cable car sites: Kasprowy Wierch (TPN, Poland) and Skalnaté Pleso (TANAP, Slovakia). The summit of KW (1987 m a.s.l.) is located in the main ridge of the Western Tatras. It is accessible by cable car and a network of designated hiking trails. SP (1772 m a.s.l.) is a mountain lake area, located next to Lomnica Peak (2634 m a.s.l., the second highest peak in the Tatras). SP may be accessed either by cable car or by designated hiking trails. However, most visitors in both study areas arrive by cable car and thus the sites belong to the most frequently visited destinations in both National Parks. The visitor load in SP reaches approximately 3000-4000 visitors per day during the summer season (Švajda \& Šturcel 2005; Hibner 2015). KW attracts on average 3000 visitors per day. How- 
Table 1 - Study area characteristics (based on: Balon \& Jodtowski 2014; Hibner \& Chlipała 2015; Konopska 2006; Streberová \& Jusková 2015; Tatra Mountains Resorts: data about number of tickets; TPN 2017; Turistický Atlas Slovenska 2005; PKL 2016; Vysokie Tatry 2016).

\begin{tabular}{|c|c|c|}
\hline Area & Kasprowy Wierch (KW), Poland & Skalnate Pleso (SP), Slovakia \\
\hline $\begin{array}{l}\text { Mountain range } \\
\text { (section) }\end{array}$ & Western Carpathians (Western Tatras) & Western Carpathians (High Tatras) \\
\hline Protected area (PA) & Tatra National Park (TPN) & Tatra National Park (TANAP) \\
\hline Area of PAs $\left(\mathrm{km}^{2}\right)$ & $212 \mathrm{~km}^{2}$ & $738 \mathrm{~km}^{2}$ \\
\hline $\begin{array}{l}\text { Summer-season } \\
\text { cable car/chairlift } \\
\text { operations }\end{array}$ & $\begin{array}{l}\text { 1. Kuźnice (1 } 030 \text { m a.s.l.) - Kasprowy Wierch (1959 m } \\
\text { a.s.l.); cable car; capacity: max. } 30 \text { per car; } 180 \text { p/h } \\
\text { (summer) }\end{array}$ & $\begin{array}{l}\text { 1. Tatranska Lomnica (903 m a.s.l.) - Štart (1 } 172 \mathrm{~m} \\
\text { a.s.l.); cable car for } 4 \text { people (900 p/h) } \\
\text { 2. Start - Skalnate Pleso (1 } 772 \mathrm{~m} \text { a.s.I.); cable car for } \\
15 \text { people }(2400 \mathrm{p} / \mathrm{h}) \\
\text { 3. Skalnate Pleso - Lomnica Peak (2634 m a.s.I.); } \\
\text { cable car for } 16 \text { people }(42 \mathrm{p} / \mathrm{h}) \\
\text { 4. Skalnate Pleso - Lomnicke Sedlo (2 } 196 \mathrm{~m} \text { a.s.l.); } \\
\text { chairlifts for } 2 \text { people; } 540 \mathrm{p} / \mathrm{h} \text { (summer) }\end{array}$ \\
\hline $\begin{array}{l}\text { Additional summer } \\
\text { offerings }\end{array}$ & $\begin{array}{l}\text { - hiking on designated trails } \\
\text { - restaurant dining } \\
\text { - viewing platform }\end{array}$ & $\begin{array}{l}\text { - hiking on designed trails } \\
\text { - restaurant dining } \\
\text { - viewing platform } \\
\text { - two playgrounds for children } \\
\text { - Fit \& Happy High Tatras programme, including: yoga, } \\
\text { Nordic Walking course, meeting with inhabitants of } \\
\text { Tatra region, environmental education activities etc. } \\
\text { - outdoor games and art workshops for children } \\
\text { - bike rental from the middle station Štart }\end{array}$ \\
\hline $\begin{array}{l}\text { Number of visitors } \\
\text { using cable car } \\
\text { (May-October 2014) }\end{array}$ & 292980 visitors (ticket up and return ticket) & $\begin{array}{l}208734 \text { visitors (incl. all types of cable cars, ticket up } \\
\text { and return ticket) }\end{array}$ \\
\hline
\end{tabular}

ever, daily visitor load in the peak season often reaches 6500-7000 people (Taczanowska et al. 2016).

The cable car to KW was built in 1936 and operates all year round. Additionally, there are two chairlifts that operate in the winter season only. The cable car to SP was built in 1938 and a second cable car, leading to Lomnica Peak, was constructed in 1940 (Zachwatowicz 1936; Bohuš 2003; Skawiński 2005) (Table 1). In the summer season, SP offers a wide range of activities. As well as riding cable cars and hiking, there is a Fit \& Happy High Tatras programme, which includes various activities, in addition to a wide offering of activities tailored to children. Tourists can also rent special bikes to ride from the middle station Štart down to Tatranska Lomnica (Vysoké Tatry 2016) (Table 1).
The tourist offering in the $\mathrm{KW}$ area is limited to hiking along designated trails and a restaurant located at the upper cable car station. In both areas, signs of overuse have been identified: trail deterioration, soil degradation and impact on flora (Degórski 2002; Rączkowska \& Kozłowska 2010; Oprządek 2014; Skiba 2015), as well as the impact on landscape perception (Jančura et al. 2009).

In order to collect data on visitor characteristics, an on-site survey (PAPI: Paper-and-Pencil Interviewing technique) was conducted by skilled interviewers directly in the two cable car areas. A total of 3304 questionnaires were collected during weekends and weekdays of the summer peak season (July - September) 2014 and $2015(\mathrm{KW} \mathrm{n}=2619$ and SP $\mathrm{n}=685$ ).

Table 2 -Motive factors and motive categories used in the study.

\begin{tabular}{|c|c|c|}
\hline $\begin{array}{l}\text { Theoretical typologies based } \\
\text { on Przecławski (1996) }\end{array}$ & $\begin{array}{l}\text { Motive categories used in } \\
\text { cluster analysis }\end{array}$ & Motives listed in the questionnaire \\
\hline cognitive type & contact with nature & $\begin{array}{l}\text { - contact with nature } \\
\text { - observation of wild animals }\end{array}$ \\
\hline \multirow[t]{2}{*}{ contemplative type } & scenery & - admiring views, scenery \\
\hline & solitude & - solitude \\
\hline rest and entertainment type & \multirow[t]{2}{*}{ rest/well-being } & $\begin{array}{l}\text { - well-being } \\
\text { - escape from noise and pollution } \\
\text { - relaxation } \\
\text { - recreation } \\
\text { - escape from urban lifestyle } \\
\text { - recovery from stress } \\
\end{array}$ \\
\hline contemplative type & & - silence \\
\hline cognitive type & education & $\begin{array}{l}\text { - sightseeing in Tatra National Park } \\
\text { - learning about geography and nature of Tatra Mountains }\end{array}$ \\
\hline active type & sport & $\begin{array}{l}\text { - improving hiking skills } \\
\text { - keeping fit } \\
\text { - physical activity }\end{array}$ \\
\hline integrative type & time with family and friends & - time with family and friends \\
\hline
\end{tabular}




\begin{tabular}{|l|l|l|l|l|}
\hline $\begin{array}{c}\text { Motive } \\
\text { categories/segments }\end{array}$ & Nature oriented & $\begin{array}{c}\text { Family / friends } \\
\text { \& well-being oriented }\end{array}$ & Sports oriented & $\begin{array}{c}\text { Mixed segment with } \\
\text { multiple motivations }\end{array}$ \\
\hline contact with nature & $50 \%$ & $7 \%$ & $20 \%$ & $88 \%$ \\
\hline scenery & $87 \%$ & $28 \%$ & $66 \%$ & $96 \%$ \\
\hline solitude & $4 \%$ & $1 \%$ & $3 \%$ & $10 \%$ \\
\hline well-being & $56 \%$ & $60 \%$ & $58 \%$ & $93 \%$ \\
\hline education & $17 \%$ & $9 \%$ & $11 \%$ & $49 \%$ \\
\hline sport & $0 \%$ & $4 \%$ & $100 \%$ & $73 \%$ \\
\hline time with family \& friends & $3 \%$ & $54 \%$ & $7 \%$ & $75 \%$ \\
\hline
\end{tabular}

Figure 2 - Motive categories within each segment.

The sampling is not equal due to the different numbers of staff carrying out the interviews in each area. The response rate in each area was slightly different. In the KW area, it was $67.4 \%$, while in the SP area it was $82 \%$. One purpose of the surveys was to gain information about tourists' motives for visiting one or other of our study areas. Answers were by multiple choice for listed motivations. Motivations corresponded to categories based on the theoretical typology of Przecławski (1996): (1) contact with nature, (2) admiring scenery, (3) solitude, (4) rest/well-being, (5) education, (6) sport, and (7) time with family and friends (Table 2). In the next step, segments of visitors based on these seven motivation categories were formed using $\mathrm{K}$-means cluster analysis (SPSS Software). A Kmeans algorithm as a partitioning clustering method is recommended for large data samples (more than 500 cases) and is a widespread clustering method in market and tourism research (Mooi \& Sarstedt 2011). Partitioning clustering methods require pre-specifying the number of segments. Following the advice of Dolnicar (2002), the K-means procedure was performed several times with different numbers of segments. Finally, a division into 4 segments turned out to be the clearest and most comprehensible solution (Figure 2). In order to gain information about the sociodemographic profile of visitors in each segment, questions such as sex, age, level of education, country of origin and group size were also included in the questionnaires. In addition, information about visitors' recreational behaviour and trip characteristics in each segment was obtained from the type of ticket used by visitors, and further data collected concerned length of stay in the Tatra region, frequency of visit, and perception of visitor load in the study area. The relationships between variables were analysed by performing cross-tabulation (Chi-square Test). SPSS software was used for statistical analysis.

\section{Results}

\section{Visitor segments}

Four distinct visitor segments based on motivational items were identified in the sample studied. Detailed characteristics of each segment are presented below.

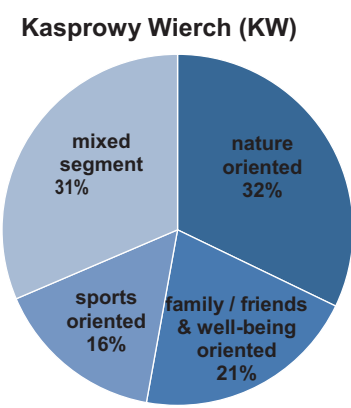

( $\mathrm{n}=\mathbf{2 6 1 9}$ )

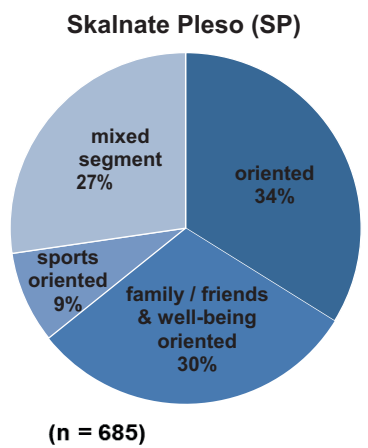

$(n=685)$
Figure 3 - Segment membership in the two study areas

\section{Segment 1: Nature oriented}

This was the largest segment in our particular research areas (KW - 32\%, SP - 34\%) (Figure 3). Scenery was an important motive for almost all segments identified, but for this one it was the dominant motive $(87 \%)$. Items such as contact with nature $(50 \%)$ as well as rest/well-being (56\%) were also important. Motivations such as sport or spending time with family and friends were typically not important for this visitor segment. Educational motivations were less important $(17 \%)$. However, in comparison with other segments, they were well represented (Figure 2).

\section{Segment 2: Family/friends \& well-being oriented}

This was also a large segment in both research areas. Moreover, it was the second largest segment among respondents from the SP area (30\%) (Figure 3). The members were motivated predominantly by items such as rest/well-being (60\%), as well as spending time with family and friends (54\%). Motivations such as contact with nature, scenery, sport or education were definitely less important for them (Figure 2).

\section{Segment 3: Sports oriented}

This was the smallest segment in the whole research sample (KW $-16 \%$, SP - 9\%) (Figure 3). Members of this segment were definitely motivated by sport $(100 \%)$, and it was the most active segment in the whole sample. However, rest/well-being (58\%) and scenery $(66 \%)$ were also important for them. Contact with nature was important for only $20 \%$ of respondents. Other motivations, such as spending time with 


\begin{tabular}{|c|c|c|c|c|c|c|c|c|c|}
\hline \multicolumn{10}{|c|}{ Sociodemographic characteristics within segments } \\
\hline \multicolumn{2}{|l|}{ Variables } & \multicolumn{2}{|c|}{ Nature oriented } & \multicolumn{2}{|c|}{$\begin{array}{c}\text { Family / friends \& } \\
\text { well-being oriented }\end{array}$} & \multicolumn{2}{|c|}{ Sports oriented } & \multicolumn{2}{|c|}{ Mixed segment } \\
\hline & & KW & SP & KW & SP & KW & SP & KW & SP \\
\hline \multirow{2}{*}{ Sex } & female & $50 \%$ & $64 \%$ & $43 \%$ & $55 \%$ & $44 \%$ & $55 \%$ & $56 \%$ & $65 \%$ \\
\hline & male & $50 \%$ & $36 \%$ & $57 \%$ & $45 \%$ & $56 \%$ & $45 \%$ & $44 \%$ & $35 \%$ \\
\hline & & \multicolumn{8}{|c|}{$\begin{array}{c}\text { KW (chi-square value: } 25.779, \text { Asymp. Sig 2-sided: } \mathbf{0 . 0 0 0} \text { ), SP (chi-square value: } \mathbf{5 . 7 6 2 ,} \\
\text { Asymp. Sig 2-sided: } \mathbf{0 . 1 2 4} \text { ) }\end{array}$} \\
\hline \multirow{7}{*}{ Age category } & less than 18 & $2 \%$ & $1 \%$ & $3 \%$ & $0 \%$ & $3 \%$ & $3 \%$ & $1 \%$ & $1 \%$ \\
\hline & range $18-24$ & $12 \%$ & $13 \%$ & $13 \%$ & $11 \%$ & $18 \%$ & $7 \%$ & $16 \%$ & $15 \%$ \\
\hline & range $25-34$ & $29 \%$ & $26 \%$ & $30 \%$ & $25 \%$ & $34 \%$ & $22 \%$ & $30 \%$ & $29 \%$ \\
\hline & range $35-44$ & $24 \%$ & $27 \%$ & $28 \%$ & $27 \%$ & $20 \%$ & $21 \%$ & $25 \%$ & $30 \%$ \\
\hline & range $45-54$ & $17 \%$ & $18 \%$ & $15 \%$ & $16 \%$ & $16 \%$ & $24 \%$ & $16 \%$ & $16 \%$ \\
\hline & range $55-64$ & $11 \%$ & $11 \%$ & $9 \%$ & $15 \%$ & $6 \%$ & $12 \%$ & $9 \%$ & $9 \%$ \\
\hline & more than 64 & $6 \%$ & $4 \%$ & $3 \%$ & $7 \%$ & $2 \%$ & $10 \%$ & $3 \%$ & $1 \%$ \\
\hline \multicolumn{2}{|l|}{ Chi-square test } & \multicolumn{8}{|c|}{$\begin{array}{l}\text { KW (chi-square value: 10.459, Asymp. Sig 2-sided: } \mathbf{0 . 0 0 2 ) , ~ S P ~ ( c h i - s q u a r e ~ v a l u e : ~} \mathbf{2 7 . 6 3 5 ,} \\
\text { Asymp. Sig 2-sided: } \mathbf{0 . 0 6 8 )}\end{array}$} \\
\hline & primary & $1 \%$ & $3 \%$ & $2 \%$ & $1 \%$ & $1 \%$ & $2 \%$ & $1 \%$ & $2 \%$ \\
\hline & trade & $8 \%$ & $7 \%$ & $7 \%$ & $3 \%$ & $4 \%$ & $2 \%$ & $4 \%$ & $1 \%$ \\
\hline & secondary & $39 \%$ & $43 \%$ & $40 \%$ & $49 \%$ & $35 \%$ & $48 \%$ & $35 \%$ & $38 \%$ \\
\hline & university & $53 \%$ & $48 \%$ & $51 \%$ & $47 \%$ & $60 \%$ & $48 \%$ & $60 \%$ & $59 \%$ \\
\hline \multicolumn{2}{|l|}{ Chi-square test } & \multicolumn{8}{|c|}{$\begin{array}{c}\text { KW (chi-square value: } 24.909 \text {, Asymp. Sig 2-sided: } 0.003 \text { ), SP (chi-square value: 16.293, } \\
\text { Asymp. Sig 2-sided: } 0.061 \text {, but poor data distribution) }\end{array}$} \\
\hline \multirow{2}{*}{$\begin{array}{l}\text { Respondents' } \\
\text { country of origin }\end{array}$} & national & $95 \%$ & $50 \%$ & $96 \%$ & $54 \%$ & $95 \%$ & $50 \%$ & $96 \%$ & $48 \%$ \\
\hline & international & $5 \%$ & $50 \%$ & $4 \%$ & $46 \%$ & $5 \%$ & $50 \%$ & $4 \%$ & $52 \%$ \\
\hline \multicolumn{2}{|l|}{ Chi-square test } & \multicolumn{8}{|c|}{ 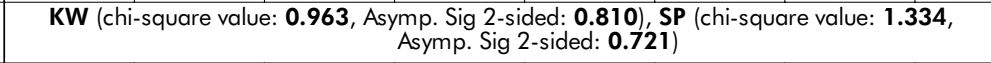 } \\
\hline \multirow{6}{*}{ Group size category } & alone & $13 \%$ & $2 \%$ & $11 \%$ & $3 \%$ & $25 \%$ & $12 \%$ & $14 \%$ & $0 \%$ \\
\hline & two people & $50 \%$ & $43 \%$ & $42 \%$ & $35 \%$ & $50 \%$ & $41 \%$ & $46 \%$ & $38 \%$ \\
\hline & 3-5 people & $33 \%$ & $39 \%$ & $42 \%$ & $43 \%$ & $21 \%$ & $31 \%$ & $35 \%$ & $49 \%$ \\
\hline & 6-9 people & $3 \%$ & $13 \%$ & $3 \%$ & $12 \%$ & $3 \%$ & $9 \%$ & $4 \%$ & $10 \%$ \\
\hline & 10-20 people & $0 \%$ & $3 \%$ & $\mid 1 \%$ & $4 \%$ & $\mid 1 \%$ & $2 \%$ & $\mid 1 \%$ & $3 \%$ \\
\hline & $>20$ people & $0 \%$ & $1 \%$ & $0 \%$ & $4 \%$ & $0 \%$ & $5 \%$ & $0 \%$ & $1 \%$ \\
\hline \multicolumn{2}{|l|}{ Chi-square test } & \multicolumn{8}{|c|}{$\begin{array}{l}\text { KW (chi-square value: } 76.690, \text { Asymp. Sig } 2 \text {-sided: } 0.000 \text { but poor data distribution), } \\
\text { SP (chi-square value: } 44.303 \text {, Asymp. Sig 2-sided: } 0.000 \text { but poor data distribution) }\end{array}$} \\
\hline
\end{tabular}

Figure $4-V$ isitor segments analysed in terms of socio-demographic variables.

family and friends or education, were of low importance for members of this segment (Figure 2).

Segment 4: Mixed segment with multiple motivations

This was the second largest segment among respondents from KW $(31 \%)$. It was also a significant segment among respondents from SP (Figure 3). Members of this visitor segment were motivated by all types of motives, although solitude figured for only $10 \%$. However, no single motivation had a dominant role within this segment (Figure 2).

Visitor segments analysed in terms of sociodemographic variables

The sociodemographic characteristics of the segments are reported in Figure 4. The segments did not differ significantly in the proportion of males to females in SP, although there were slightly more females in each segment in this location. However, significant differences in the proportions of males and females were observed in the area of KW. Compared to the nature-oriented and mixed segments, in the family / friends \& well-being segment as well as the sports-oriented segment slightly more males were encountered. In fact, there were also relatively fewer females in SP in the family / friends \& well-being and sports-oriented segments in comparison with other segments (Figure 4).

There were no significant differences between tourist segments and the age category, although there were some differences between the two research areas in terms of age. The largest age category among respondents from KW was 25-34 years; about 30\% of respondents from each segment belonged to this category. Respondents from SP were slightly older. The largest age category here was 35-44 years (30\%) (Figure 4).

In terms of educational level, the whole sample was dominated by visitors with university degrees. Nevertheless, a higher percentage of visitors with university degrees was observed in the mixed and sports segments (about $60 \%$ ). The lowest percentage of visitors with a university degree was observed in the family \& well-being segment (Figure 4).

The segments did not differ significantly regarding the respondents' country of origin. However, a significant difference was noticed between the two research areas. In KW (Poland), the whole sample was dominated by visitors from Poland (more than $90 \%$ in each 


\begin{tabular}{|c|c|c|c|c|c|c|c|c|c|}
\hline \multicolumn{10}{|c|}{ Trip characteristics within segments } \\
\hline \multirow{2}{*}{\multicolumn{2}{|c|}{ Variables }} & \multicolumn{2}{|c|}{ Nature oriented } & \multicolumn{2}{|c|}{$\begin{array}{c}\text { Family / friends \& } \\
\text { well-being }\end{array}$} & \multicolumn{2}{|c|}{ Sports oriented } & \multicolumn{2}{|c|}{ Mixed segment } \\
\hline & & KW & SP & KW & SP & KW & SP & KW & SP \\
\hline \multirow{6}{*}{$\begin{array}{l}\text { Trip type / Ticket } \\
\text { type }\end{array}$} & return ticket & $54 \%$ & $58 \%$ & $60 \%$ & $55 \%$ & $18 \%$ & $29 \%$ & $24 \%$ & $40 \%$ \\
\hline & ticket up & $23 \%$ & $14 \%$ & $13 \%$ & $17 \%$ & $26 \%$ & $17 \%$ & $28 \%$ & $19 \%$ \\
\hline & ticket down & $10 \%$ & $8 \%$ & $13 \%$ & $8 \%$ & $20 \%$ & $5 \%$ & $14 \%$ & $8 \%$ \\
\hline & on foot & $14 \%$ & $16 \%$ & $4 \%$ & $13 \%$ & $36 \%$ & $41 \%$ & $33 \%$ & $28 \%$ \\
\hline & mixed type (SP) & & $1 \%$ & & $\mid 1 \%$ & & $5 \%$ & & $2 \%$ \\
\hline & other (SP) & & $3 \%$ & & $5 \%$ & & $2 \%$ & & $4 \%$ \\
\hline \multicolumn{2}{|l|}{ Chi-square test } & \multicolumn{8}{|c|}{$\begin{array}{c}\text { KW (chi-square value: } \mathbf{3 6 7 . 4 7 0 ,} \text { Asymp. Sig 2-sided: } \mathbf{0 . 0 0 0 ) , ~ S P ~ ( c h i - s q u a r e ~ v a l u e : ~} 48.087 \\
\text { Asymp. Sig 2-sided: } \mathbf{0 . 0 0 0 )}\end{array}$} \\
\hline \multirow{6}{*}{ Length of the stay } & 1 day & $5 \%$ & $9 \%$ & $6 \%$ & $14 \%$ & $5 \%$ & $9 \%$ & $4 \%$ & $14 \%$ \\
\hline & 2 days & $6 \%$ & $10 \%$ & $5 \%$ & $13 \%$ & $5 \%$ & $2 \%$ & $5 \%$ & $10 \%$ \\
\hline & $3-5$ days & $37 \%$ & $49 \%$ & $46 \%$ & $45 \%$ & $41 \%$ & $36 \%$ & $36 \%$ & $37 \%$ \\
\hline & 6-7 days & $33 \%$ & $23 \%$ & $29 \%$ & $21 \%$ & $33 \%$ & $28 \%$ & $34 \%$ & $26 \%$ \\
\hline & more than 7 days & $19 \%$ & $9 \%$ & $13 \%$ & $7 \%$ & $17 \%$ & $26 \%$ & $21 \%$ & $12 \%$ \\
\hline & local residents & & $0 \%$ & & $0 \%$ & & $0 \%$ & & $\mid 1 \%$ \\
\hline \multicolumn{2}{|l|}{ Chi-square test } & \multicolumn{8}{|c|}{$\begin{array}{c}\text { KW (chi-square value: } 28.345, \text { Asymp. Sig 2-sided: } 0.005 \text { ), SP (chi-square value: 34.641, } \\
\text { Asymp. Sig 2-sided: } 0.003 \text { ) }\end{array}$} \\
\hline \multirow{6}{*}{ Frequency of visit } & local residents & $0 \%$ & $0 \%$ & $2 \%$ & $0 \%$ & $3 \%$ & $0 \%$ & $1 \%$ & $0 \%$ \\
\hline & first time & $19 \%$ & $22 \%$ & $17 \%$ & $24 \%$ & $11 \%$ & $14 \%$ & $13 \%$ & $25 \%$ \\
\hline & very seldom & $10 \%$ & $18 \%$ & $10 \%$ & $14 \%$ & $7 \%$ & $16 \%$ & $9 \%$ & $13 \%$ \\
\hline & every couple of years & $29 \%$ & $21 \%$ & $31 \%$ & $19 \%$ & $25 \%$ & $22 \%$ & $26 \%$ & $14 \%$ \\
\hline & once a year & $29 \%$ & $21 \%$ & $24 \%$ & $25 \%$ & $31 \%$ & $26 \%$ & $31 \%$ & $23 \%$ \\
\hline & several times a year & $12 \%$ & $18 \%$ & $15 \%$ & $17 \%$ & $23 \%$ & $22 \%$ & $20 \%$ & $24 \%$ \\
\hline \multicolumn{2}{|l|}{ Chi-square test } & \multicolumn{8}{|c|}{$\begin{array}{c}\text { KW (chi-square value: 79.003, Asymp. Sig 2-sided: } \mathbf{0 . 0 0 0 ) , ~ S P ~ ( c h i - s q u a r e ~ v a l u e : ~ 1 3 . 1 8 1 , ~} \\
\text { Asymp. Sig 2-sided: } \mathbf{0 . 5 8 8} \text { ) }\end{array}$} \\
\hline \multirow{4}{*}{$\begin{array}{l}\text { Perception of } \\
\text { visitor load }\end{array}$} & too few visitors & $5 \%$ & $3 \%$ & $3 \%$ & $6 \%$ & $4 \%$ & $4 \%$ & $4 \%$ & $3 \%$ \\
\hline & fine / ok & $62 \%$ & $74 \%$ & $62 \%$ & $69 \%$ & $56 \%$ & $67 \%$ & $64 \%$ & $72 \%$ \\
\hline & too many visitors & $31 \%$ & $22 \%$ & $32 \%$ & $25 \%$ & $37 \%$ & $27 \%$ & $30 \%$ & $24 \%$ \\
\hline & difficult to say & $3 \%$ & $1 \%$ & $3 \%$ & $2 \%$ & $3 \%$ & $2 \%$ & $2 \%$ & $1 \%$ \\
\hline \multicolumn{2}{|l|}{ Chi-square test } & \multicolumn{8}{|c|}{$\begin{array}{l}\text { KW (chi-square value: } 25.451, \text { Asymp. Sig 2-sided: } 0.228 \text {, but poor data distribution), } \\
\text { SP (chi-square value: } 7.344 \text { Asymp. Sig 2-sided: } 0.834 \text {, but poor data distribution) }\end{array}$} \\
\hline
\end{tabular}

Figure 5 - Visitor segments analysed in terms of trip characteristics.

segment). In comparison, in SP (Slovakia) only about $50 \%$ of respondents were from Slovakia. Most of the foreign visitors came from Poland and the Czech Republic (Figure 4).

Where the size of the visitor groups is concerned, the largest categories over the whole sample are the 2-person group and the small-group category (3-5 people). There were small significant differences among segments in terms of this variable. In the nature- and sports-oriented segments, a predominance of the 2-person group was observed, especially in $\mathrm{KW}$ $(50 \%)$. The highest percentage of visitors on their own was observed in the sports segment (Figure 4).

Visitor types analysed in terms of trip characteristics

Trip characteristics of the segments are reported in Figure 5. In general, visitors have a choice of three types of ticket: ticket up, ticket down and return ticket. In KW, visitors who buy a return ticket are allowed to stay for only $1 \mathrm{hr} 30 \mathrm{mins}$ in the mountain area. Visitors to the SP area do not have a time limit on the return ticket, and can thus go for longer walks. In order to unify the ticket types for this study, the term return ticket was used only for visitors who did not go for any longer walks during their stay in the SP area. Respondents who went on longer walks and also used a cable car up and down were designated mixed type of ticket. The highest percentages of visitors with return tickets were found in the family / friends \& well-being oriented segment (about $60 \%$ ), and in the nature-oriented segment (about 50\%). The lowest percentage of visitors who did not use a cable car at all was also observed in the family/friends \& well-being segment (about 14\%). Similarly, the highest percentage of visitors who did not use a cable car was observed in the sports-oriented segment. Thus, the lowest percentage of visitors with a return ticket can be seen in the sports segment (Figure 5).

There were no significant differences between tourist segments for the length of the stay in the region. The largest categories of stay in the whole sample were 3-5 days and 6-7 days. Together they comprised more than $60 \%$ of tourists in each segment (Figure 5).

Visitors were also asked about the frequency of their visits to the Tatras. This variable reveals differences between segments in the whole sample as well as in terms of the KW area. According to the statistical test, the variable did not differ significantly for segments in the SP area. The lowest frequency of visit 
was observed in the family / friends \& well-being segment, which is also the least active among all segments. A lower frequency of visit was also observed in the nature-oriented segment, while the highest frequency of visit was observed among the sports-oriented segment. A higher frequency of visit was also observed in the mixed segment (Figure 5).

There were no significant differences between visitor segments for perception of visitor load. More than half of the sample agreed that the numbers of visitors in the research areas were at an acceptable level. In the sports-oriented segment, slightly fewer respondents accepted this assessment of visitor load. However, some differences were noticed between the research areas. Slightly more visitors to SP found the visitor load acceptable (KW - about $60 \%$, SP - about $70 \%$ ) (Figure 5).

\section{Discussion}

Comparison with other visitor profiling studies

This paper discusses visiting motives among respondents to two cable car areas in the Tatra Mountains. The following four motive categories were found to be the most differentiating ones: contact with nature, admiring scenery, time with family and friends, and sport reasons. According to the literature, nature plays an important role in outdoor recreation. For instance, Needham et al. (2010) grouped visitors to Whistler Mountain (British Columbia) into three segments, among which cluster no. 3 was nature oriented. Variables such as nature and time with family and friends were also found in Bieger and Laesser (2002). Some of the motives listed in the questionnaire in our study correspond to motive categories used by Konu and Kajala (2012). However, segments found in the Finnish study (Konu \& Kajala) do not correspond well with our results. In the Finnish study, nature was important for all four segments identified there, whereas in our study it was not important to all segments. Konu and Kajala also identified sport, well-being and relaxation motivations. Segmentation among canoeists in the Donau-Auen National Park, Austria, seems to be quite similar in terms of visitor types. Four distinct segments were also identified there: family \& friends type, sports type, nature type and recreation type (Sterl et al. 2006). Where theoretical studies are concerned, the visitor typology based on Przecławski (1996) corresponds well with our segmentation. However, Przecławski distinguishes 7 types of visitors. Another theoretical study based on a purism scale seems to be similar to our study in terms of appreciation of nature and accepting the presence of infrastructure within the protected area (Stankey 1973). On the purism scale, visitors are divided into three segments: (1) purists (the most sensitive segment), who prefer untouched natural areas; this segment corresponds well with our nature-oriented and mixed segments; (2) urbanists (a less sensitive segment), who are more likely to accept infrastructure in natural areas; this segment corresponds with our family/friends \& well-being segments; (3) neutralists this segment is somewhere between purists and urbanists. We suggest that this segment could be somehow comparable with the sports-oriented segment. While the sports segment appreciate admiring scenery (66\%), this segment is definitely not motivated by contact with nature $(20 \%)$. Moreover, the segment is more active, which means that in this segment there is a high percentage of visitors who do not use a cable car.

\section{Comparison with other mountain areas}

Sociodemographic information identified in this study, such as the predominance of males in some more active segments and predominance of young and well-educated visitors, is comparable with other studies conducted previously in these locations (Marchlewski 2005; Szydarowski 2010; Taczanowska et al. 2014). In comparison with the results from other mountain areas, e.g. the Austrian Alps (Muhar et al. 2007), visitors in the Tatra Mountains, particularly in $\mathrm{KW}$, are younger. The age of Alpine visitors varied from 30 to 60 years old, which is probably connected with general societal physical activity levels in Poland. According to Biernat and Piątkowska (2012), people in Poland (especially older people) are less active than people in other European countries (Beedie \& Hudson 2003; Biernat \& Piątkowska 2012). Visitors with university degrees were also the largest proportion in the Austrian Alps; however, the percentage of visitors with completed tertiary education is slightly closer to the results from SP than from KW. Variables such as group size are similar in the Tatras and in the Austrian Alps.

Implications of the results for PA management

The functions of PAs, and more specifically national parks, are nature conservation along with social functions, such as recreation, research and educational functions (Dudley 2008). The results presented here may support PA management decisions related to recreation and education in cable car areas, which are among the most heavily-used destinations in PAs. The most critical management issue is the number of visitors and the related impact on the environment. One possible strategy of the PA managers to preserve more sensitive and more vulnerable areas (Gulič et al. 2014) would be to identify some less vulnerable areas (e.g. with existing infrastructure) and offer these as their main tourist attractions. This is also a desirable solution from the point of view of the cable car operators, who aim to attract large numbers of visitors. For instance, in the KW area there is ongoing discussion concerning the possibility of increasing cable car capacity (Taczanowska et al. 2016). However, the visitor concentration should not exceed the environmental and social capacity of a particular area. In both cable car destinations, in the peak season, it seems that the limits have already been reached and solutions 
for decreasing the visitor load should be considered. Our results show that the majority of visitors in the study are less active. Visitors with low motivation for physical activity (nature-oriented and family / friends \& well-being oriented segments) are the most frequent tourists in the study areas. Potential target groups that could be attracted by other hiking destinations are sports-oriented visitors and our mixed visitor segment.

Next to recreation, environmental education plays an important social function in PAs. More than half the respondents were nature oriented (approximately $60 \%$ - nature-oriented and mixed segments combined). They also declared the wish to expand their knowledge about the Tatras. These motivations correspond well with the conservation tourism philosophy traditionally practised in PAs. This form of tourism should be strengthened in the National Parks. We suggest supporting educational offerings in these areas (e.g. information panels related to geology and the protected fauna and flora in the proximity of the cable car stations, panoramic boards, thematic mobile applications, free meetings and discussions with PA staff about natural features etc.) Several elements have already been introduced in the study areas (e. g. information panels in Skalnate Pleso). However, a better integration of such infrastructure with the surrounding landscape is desirable.

The results also show that there is a great need to increase awareness, in particular in terms of the appreciation of nature, since there are a large number of tourists exclusively interested in leisure rather than in the natural environment. Cable car areas in particular attract a large number of visitors motivated mainly by social aspects (family / friends \& well-being). This is a great opportunity for national parks to promote nature protection and environmentally friendly behaviour among casual tourists. Thus, environmental education is one of the most important missions of the PAs. Visitors who are less familiar with mountain environments and the risks related to hiking in alpine areas should be specially supported. Specific information including orientation, trail difficulty and possible weather changes, along with the required personal physical condition and hiking equipment should be promoted to people prior to using the cable car. Possible information channels would be web-services in places of overnight stay and cable car areas, ticket offices, and mobile applications.

Strengths and weaknesses of the applied methods

A major strength of this work is the large sample of respondents to the survey, which enhances the credibility of the findings. Moreover, the study was conducted in two different mountain PAs (in Poland and Slovakia), characterized by two different institutional environments with different views on tourism development in cable car destinations. This enabled a better comparison between areas and their respec- tive visitor profiles. Furthermore, a close relationship between visitor segments and tourist behaviour was observed in this study. For instance, family / friends \& well-being oriented visitors are more likely to purchase return cable car tickets, whereas the sports-oriented tourist segment is more active and does not usually use cable cars. Visitor profiles as defined in our study could be used practically in PA management.

One of the limitations of our work is the design of the questionnaire: there were relatively few questions, and responses regarding visitor motivation were confined to multiple-choice options. The main concern in designing the questionnaire was to reduce its completion time in order to reduce the drop-out rate during the interview. As the study showed that approximately one third of visitors interviewed were not explicitly interested in nature, it is necessary to explore this issue in detail in future studies. The interview section, which concerned general environmental awareness and knowledge of the natural features of the area, could be extended in future studies.

Another discussion point refers to the clustering methodology applied. K-means clustering is an established method, used in visitor profiling within outdoor recreation research (Sterl et al. 2006; Park \& Yoon 2009; Konu \& Kajala 2012) and market research (Mooi \& Sarstedt 2011). It is a partitioning clustering method. An alternative solution would be to use hierarchical clustering. However, $\mathrm{K}$-means clustering is advantageous for large data samples (Dolnicar 2002; Mooi \& Sarstedt 2011). Moreover, it is also often found in empirical studies based on psychographic factors (Kastenholz et al. 1999; Frochot 2005; Sterl et al. 2006; Molera \& Albaladejo 2007; Park \& Yoon 2009; Rid et al. 2014; Konu \& Kajala 2012; Smith et al. 2014). There are other exploratory approaches used for grouping cases, such as neural network selforganizing maps (SOM) (Oja et al. 2003) and fuzzy logic segmentation (D'Urso et al. 2016), which may be promising and worth applying.

\section{Conclusions}

There is a large group of visitors (i.e., the family / friends \& well-being and sports segments) with little explicit interest in nature experience. In particular, visitors from the family / friends \& well-being segment are less interested in nature and landscape values. Visitors from this segment focus mostly on spending time with family and friends, or on values connected with rest and relaxation. This is a large segment, especially in the SP research area.

The results show one important difference among segment membership between the two study areas. As mentioned above the family / friends \& well-being segment is a very important group of visitors in the SP research area. This is probably the result of the wide range of tourist attractions offered in this area (Table 1). 
Sociodemographic variables did not reveal large differences among segments. This is probably related to the particular study areas where the research was conducted. Perhaps comparison with non-cable car areas would present more differences. Variables based on trip characteristics better identified the differences among segments, especially in terms of types of ticket as well as frequency of visits. The segments identified correspond well with type of cable car ticket purchased. The family / friends \& well-being segment, which is less interested in sport or nature values, is also less active. Consequently visitors from this segment are more likely to use a cable car in both directions (more than half of respondents from this segment bought return tickets). Similarly, the sports-oriented visitors are more active in comparison with others. Surprisingly, visitors from the nature-oriented segment were also more likely to use a cable car.

The visitor segments identified in this study could be used practically in the management of cable car destinations located within PAs. PAs could use the results primarily for social marketing purposes, such as environmental education of visitors and promoting the general concept of nature protection. The results presented here could also be used by cable car operators and local stakeholders in destination management and commercial tourist product development that respect the principles of sustainable tourism.

\section{Acknowledgements}

Data were collected as part of two research projects: (1) Visitor monitoring in the Tatra National Park - a pilot study - Kasprowy Wierch, conducted by the Institute of Landscape Development, Recreation and Conservation Planning, University of Natural Resources and Life Sciences (BOKU) in cooperation with Tatra National Park (TPN); (2) Characteristics of tourists' movements in the Skalnaté Pleso Area (as a part of a doctoral thesis at Jagiellonian University, Cracow, Poland).

The authors are grateful to the Management and Staff of the Tatra National Park (Poland). Special thanks to Szymon Ziobrowski and Paweł Skawiński for initiating cooperation and supporting the project idea. The authors also wish to thank the cable car operators (Polskie Koleje Linowe - Kasprowy Wierch and Tatra Mountain Resorts - Skalnate Pleso) for sharing data and extend their special thanks to all people involved in the field work.

\section{References}

Ankre, R. 2005. Visitor activities and attitudes in coastal areas: A Case Study of the Lulea archipelago, Sweden. Östersund: ETOUR: 1-82

Arnberger, A. \& W. Haider 2005. Social effects on crowding preferences of urban forest visitors. Urban Forestry \& Urban Greening 3: 125-136.
Balon, J. \& M. Jodłowski 2014. Regionalizacja fizycznogeograficzna Karpat Zachodnich - studium metodologiczne. In: Ziaja, W. \& M. Jodłowski (eds.), Struktura środowiska prayrodniczego a fizjonomia kerajobrazu: 85-106. [In Polish]

Beedie, P. \& S. Hudson 2003. Emergence of mountain-based adventure tourism. Annals of Tourism Research 30(3): 625-643.

Biernat, E. \& M. Piątkowska 2012, Rekreacyjna aketywnośc fizyczna Polaków na tle Europy. Raport dla Departamentu Analiz i Polityki Sportowej Ministerstwa Sportu i Turystyki: 1-39. [In Polish]

Bieger, T. \& C. Laesser 2002. Market Segmentation by Motivation: The Case of Switzerland. Journal of Travel Research 41: 68-76

Bohuš, I. 2003. Vysoké Tatry : rozprávanie o názvoch a o prvých vyistupoch na tatranské vrcholy. [In Slovak]

Buckley, R.C. 2010. Conservation Tourism. Wallingford, Oxfordshire, UK; Cambridge, MA

Burns, R.C. \& A.R. Graefe 2002. Segmentation of Outdoor Recreationists: A Comparison of Recreationists' Perceptions of Importance and Satisfaction Across Activities. In: Arnberger, A., C. Brandenburg \& A. Muhar (eds.), Monitoring and Management of Visitor Flows in Recreational and Protected Areas. Conference Proceedings: 122-128.

Cessford, G. \& A. Muhar 2003. Monitoring options for visitor numbers in national parks and natural areas. Journal for Nature Conservation 11(4): 240-250.

Cohen, E. 1979. Rethinking the sociology of tourism. Annals of Tourism Research (Jan/Mar): 18-35

Degórski, M. 2002. Ocena wpływu antropopresji na wybrane właściwości pokrywy glebowej piętra subalpejskiego i alpejskiego w rejonie Kasprowego Wierchu. In: Borowiec, W., A. Kotarba, A. Kownacki, Z. Krzan \& Z. Mirek (eds.), Przemiany środowiska prayrodniczego Tatr: 395-402. Zakopane. [In Polish]

Dolnicar, S. 2002. A Review of Data-Driven Market Segmentation in Tourism. Journal of Travel \& Tourism Marketing 12(1): 1-22.

Dolnicar, S. \& B. Grün 2008. Challenging "Factor-Cluster Segmentation". Journal of Travel Research 47: $63-71$

D’Urso, P., M. Disegna, R. Massari \& L. Osti 2016. Fuzzy segmentation of postmodern tourists. Tourism Management 55: 297-308.

Dudley, N. (ed.) 2008. Guidelines for Applying Protected Area Management Categories. Gland, Switzerland: IUCN.

Eagles, P.F.J., S.F. McCool \& C.D.A. Haynes 2002. Sustainable Tourism in Protected Areas: Guidlines for planning and management. IUCN. Gland Switzerland, Cambridge UK.

Farías Torbidoni, E.I., H.R. Grau \& A. Camps 2005. Trail Preferences and Visitor Characteristics in Aigüestortes i Estany de Sant Maurici National Park, Spain. Mountain Research and Development 25(1): 51-59

Frochot, I. 2005. A benefit segmentation of tourists in rural areas: a Scottish perspective. Tourism Management 26: 335-346. 
Galloway, G. 2002. Psychographic segmentation of park visitor markets: evidence for the utility of sensation seeking. Tourism Management 23: 581-596.

Gulič, J., S. Štruc \& N. Debeljak Šabec 2014. Monitoring and management of visitors on Pohorje Mountain active raised bogs (Slovenia). In: Reimann, M., K. Sepp, E. Pärna \& R. Tuula (eds.), The $7^{\text {th }}$ International Conference on Monitoring and Management of Visitors in Recreational and Protected Areas (MMV) Local Community and Outdoor Recreation, August 20-23, 2014 Tallinn, Estonia Proceedings: 175-176.

Gundersen Engeset, M. \& J. Velvin 2016. From Winter Destination to All-yearround Tourism: How Focus on Service can Reduce Fluctuation in Demand due to Seasonality. In: Richins, H. \& J.S. Hull (eds.), Mountain Tourism: Experiences, Communities, Environments and Sustainable Futures: 79-87

Haley, R.I. 1968. Benefit Segmentation: A Decision-oriented Research Tool. Journal of Marketing 32: 30-35.

Hibner, J. 2015. Natężenie ruchu turystycznego w rejonie Łomnickiego Stawu (Słowacja) w okresie lipiec - październik 2014 r. In: Liro, J., M. Liro \& P. Krąż (eds.), Wspótczesne problemy i kierunki badawcze w geografii 3: 73-90. [In Polish]

IUCN 2016. Red List of Ecosystems. Available at: https://www.iucn.org/about/union/commissions/ cem/cem_work/tg_red_list/ (accessed 28/03/2016)

Jančura, P., B. Beláček, I. Bohálová \& M. Slámová 2009. Scientific significance of visualisation methods for expression of selected attributes of landscape character of the High Tatra Mountains. Landform Analysis 10: 44-49.

Kastenholz, E., D. Davis \& G. Paul 1999. Segmenting Tourism in Rural Areas: The Case of North and Central Portugal. Journal of Travel Research 37: 353-363.

Kohl, I. \& R. Pekny 2011. Management in the Dürrenstein Wilderness Area - How much human intervention can the wilderness tolerate? eco.mont Journal on Protected Mountain Areas Research and Management 3(1): 51-54

Konopska, B. (ed.) 2006. Mapa turystyczna Tatraański Park Narodowy. wyd. 2 (1:30 000). Warszawa, PPWK im. E. Romera. [In Polish]

Konu, H. \& L. Kajala 2012. Segmenting Protected Area Visitors Based on Their Motivations. Nature Protection Publications of Metsähallitus. Series A 194: 1-74.

Leung, Y.-F., A. Spenceley, G. Hvenegaard \& R. Buckley 2015. Tourism and Visitor Management in Protected Areas: Guidelines towards sustainability. Best Practice Protected Area Guidelines Series. Gland, Switzerland: IUCN

Li, C-L., C.H. Zinn, G.E. Chick, J.D. Absher \& A.R. Graefe 2006. Segmentation of Visitors' CrossCultural Values in Forest Recreation. In: Siegrist, D., C. Clivaz, M. Hunziker \& S. Iten (eds.), Exploring the Nature of Management. Proceedings of the Third International Conference on Monitoring and Management of Visitor Flows in Recreational and Protected Areas. University of Applied
Sciences Rapperswil, Switzerland, 13-17 September 2006. Rapperswil: 331-335.

Marchlewski, A. 2005. Badania ankietowe na terenie Tatrzańskiego Parku Narodowego. In: Ladygin, Z. \& B. Chovancová (eds.), Monitoring ruchu turystycznego $w$ Tatrach. Monitoring návštevnosti Tatier: 65-76. TPN. Zakopane. [In Polish and Slovak]

Mayer, M. 2009. Innovation as a Success Factor in Tourism: Empirical Evidence from Western Austrian Cable-Car Companies. Erdkunde 63(2): 123-139.

Molera, L. \& I.P. Albaladejo 2007. Profiling segments of tourists in rural areas of South-Eastern Spain. Tourism Management 28: 757-767

Mooi, E. \& M. Sarstedt. 2011. A Concise Guide to Market Research. DOI 10.1007/978-3-642-12541-6_9. Berlin, Heidelberg.

Moscardo, G., Pearce, P. \& A. Morrison 2001. Evaluating Different Bases for Market Segmentation. Journal of Travel \& Tourism Marketing 10(1): 29-49.

Muhar, A., T. Schauppenlehner, C. Brandenburg \& A. Arnberger 2007. Alpine summer tourism: the mountaineers' perspective and consequences for tourism strategies in Austria. Forest Snow Landscape Research 81(1/2): 7-17

Needham, M.D., C.J.B. Wood \& R. B. Rollins 2004. Understanding Summer Visitors and Their Experiences at the Whistler Mountain Ski Area, Canada. Mountain Research and Development 24(3): 234-242.

Needham, M.D., R.B. Rollins, R.L. Ceurvorst, C.J.B. Wood, K.E. Grimm \& P. Dearden 2010. Motivations and Normative Evaluations of Summer Visitors at an Alpine Ski Area. Journal of Travel Research 20(10): 1-16.

Park, D-B. \& Y-S. Yoon 2009. Segmentation by motivation in rural tourism: A Korean case study. Tourism Management 30: 99-108.

Newsome, D. 2002. Natural Area Tourism: Ecology, Impacts and Management.

Oja, M., S. Kaski \& T. Kohonen 2003. Bibliography of Self-Organizing Map (SOM) papers: 1998-2001. Addendum. Neural Computing Surveys 3: 1-156.

Oprządek, M. 2014. Changes in vegetation structure along four tourist trails from Kasprowy Wierch, Tatra Mountains. Journal of Environmental and Tourism Analyses 2(1): 75-82

Plummer, R. \& D.A. Fennell 2009. Managing protected areas for sustainable tourism: Prospects for adaptive co-management. Journal of Sustainable Tourism 17: 149-168.

Przecławski, K. 1996. Człowiek a turystyka. Zarys socjologii turystyki. [In Polish]

Rączkowska, Z. \& A. Kozłowska 2010. Wpływ turystyki na rzeźbę i roślinność przy ścieżkach w otoczeniu Kasprowego Wierchu. In: Krzan, Z. (ed.), Nauka a zarzadzanie obszarem Tatr i ich otoczeniem v. III Człowiek. $i$ środowisko. 21-28. [In Polish]

Rid, W., I.O. Ezeuduji \& U. Pröbstl-Haider 2014. Segmentation by motivation for rural tourism activities in The Gambia. Tourism Management 40: 102-116. 
Skawiński, P. 2005. Ochrona i udostępnianie Tatrzańskiego Parku Narodowego; stan obecny i wizja przyszłości. In: Krzan, Z. (ed.), Przyroda Tatrzanskiego Parku Narodowego a czlowiek 2005. Tatrzanskei Park Narodowy na tle innych górskich terenów chronionych,v. III, Zakopane. [In Polish]

Skiba, S., M. Drewnik, W. Szymański \& M. Skiba 2015. Monitoring przyrodniczy i próba rekultywacji pokrywy glebowej i szaty roślinnej w sąsiedztwie szlaku turystycznego w rejonie wzmożonego ruchu na odcinku Kasprowy Wierch-Beskid. In: Chrobak, A. \& T. Zwijacz-Kozica (eds.), Nauka Tatrom. Tom 3. Catowiek $i$ środowisko. Materiaty $V$ Konferencji Prayroda Tatrzańskiego Parku Narodowego a Cztowiek, Zakopane. 24-26 września 2015 roku. Zakopane: 119-125. [In Polish]

Smith, A.J., M. Tuffin, R.H. Taplin, S.A. Moore \& J. Tonge 2014. Visitor segmentation for a park system using research and managerial judgement. Journal of Ecotourism 13: 93-109.

Stankey, G. 1973. Visitor perception of wilderness recreation carrying capacity. USDA Forest Service Research paper INT-142 1973. Intermountain Forest and Range Experiment Station, Ogden, Utah.

Sterl, P., S. Wagner \& A. Arnberger 2006. Kanufahrer und ihre Präferenzen für Besucherzahlen - Untersuchungen zur Erholungsqualität im Nationalpark Donau-Auen, Österreich. Naturschutz und Landschaftsplanung 38(3): 75-80. [In German]

Streberová, E. \& L. Jusková 2015. Standards of quality for outdoor recreation in Tatra National Park: a contribution to integrated visitor monitoring and management. eco.mont - Journal on Protected Mountain Areas Research and Management 7(1): 56-65.

Švajda, J. 2009. Contribution for Improvement of Visitor Monitoring in the Tatra National Park. eco. mont - Journal on Protected Mountain Areas Research and Management 1(2): 13-18.

Švajda, J. \& M. Šturcel 2005. Turystyka w wysokogórskim środowisku Tatr Słowackich. In: Ladygin, Z. \& B. Chovancová (eds), Monitoring ruchu turystycznego w Tatrach: 2005: 37-42. [In Polish and Slovak]

Szydarowski, W. 2000. Ruch turystyczny na obszarze Tatrzańskiego Parku Narodowego w świetle badań ankietowych. In: Czochański, J.T. \& D. Borowiak (eds.), $Z$ badań geograficznych w Tatrach Polskich; 25-lecie badań Uniwersytetu Gdańskiego: 231-237. [In Polish]

Taczanowska, K., A. Arnberger \& A. Muhar 2006. Exploring spatial behaviour of visitors in peri-urban recreational areas: multi-attribute analysis of individual route profiles. Paper presented at the CORP 2006: $11^{\text {th }}$ International Conference on Urban Planning \& Regional Development in the Information Society. February 13-16 2006, Vienna, Austria.

Taczanowska, K., A. Zięba, C. Brandenburg, A. Muhar, H. Preisel, S. Zięba, J. Krzeptowski, A. Krajewska, K. Kamińska, B. Latosińska, J. Hibner, W. Makaruk, K. Hat-Pawlikowska, H. Sostmann, C. Graf,
R. Benitez, V. Bolos, L.M. Gonzalez, X. Garcia, J.L. Toca-Herrera, S. Zmrzlikar \& S. Ziobrowski 2016. Visitor monitoring in the Tatra National Park - a pilot study - Kasprowy Wierch [Monitorig ruchu turystycznego w Tatrzańskim Parku Narodowym - studium pilotażowe - Kasprowy Wierch 2014]. Institute of Landscape Development, Recreation and Conservation Planning, University of Natural Resources and Life Sciences (BOKU), Tatrzański Park Narodowy. Final Report, 03.04.2016. In Polish

TPN 2016. Available at: http://tpn.pl/zwiedzaj/ turystyka/statystyka (accessed: 01/07/2016)

TPN 2017 Available at: http://tpn.pl/poznaj (accessed: 27/07/2017)

Turistický Atlas Slovenska 1:50000 2005. VKU, Hramanec.

Van Marwijk, R. \& K. Taczanowska 2006. Types of Typologies -

From Recreationists \& Tourists to Artificial Agents. In: Siegrist, D., C. Clivaz, M. Hunziker \& S. Iten (eds.), Exploring the Nature of Management. Proceedings of the Third International Conference on Monitoring and Management of Visitor Flows in Recreational and Protected Areas. University of Applied Sciences Rapperswil, Switzerland, 13-17 September 2006. Rapperswil: 499-501.

Vysoké Tatry, Fit \& Happy Tatras. Available at: http://www.vt.sk/en/mountains/summer-holiday/ news/fit-happy-high-tatras/ (accessed: 01/07/16)

Zachwatowicz, J. 1936. Kolej linowa na Kasprowy Wierch. Architektura i Budownictwo: miesiecrnik ilustrowany XII (12): 385-392. Warszawa. [In Polish]

\section{Authors}

Joanna Hibner - corresponding author ${ }^{1}$

is a $\mathrm{PhD}$ student at the Institute of Geography and Spatial Management, Jagiellonian University in Cracow. Her main research interests are monitoring and management of visitors in protected areas, mountain protected areas and landscape perception. E-mail: joanna.hibner@doctoral.uj.edu.pl

Karolina Taczanowska - corresponding author ${ }^{2}$

is a senior lecturer and researcher at the Institute of Landscape Development, Recreation and Conservation Planning at the University of Natural Resources and Life Sciences (BOKU) in Vienna, Austria. Her research focuses on sustainable tourism and outdoor recreation, with a specific interest in the spatial behaviour of visitors in natural environments. E-mail: karolina.taczanowska@boku.ac.at

\section{Antoni Zięba ${ }^{3}$}

is a nature conservation specialist at the Tatra National Park (Poland), Department of Research and Monitoring. His research focuses on mountain forests and alpine flora, as well as landscape-based tourism. 
Christiane Brandenburg ${ }^{2}$

is an associate professor and head of the Institute of Landscape Development, Recreation and Conservation Planning at the University of Natural Resources and Life Sciences (BOKU) in Vienna, Austria. Her expertise lies in the modelling and monitoring of leisure activities in natural settings within the context of nature conservation.

\section{Andreas Muhar ${ }^{2}$}

is a professor at the Institute of Landscape Development, Recreation and Conservation Planning at BOKU, the University of Natural Resources and Life Sciences Vienna. His research focuses on sustainable landscape development, landscape-based tourism and transdisciplinary knowledge integration.

Jarosław Balon'

is an assistant professor at the Institute of Geography and Spatial Management, Jagiellonian University in Cracow. His main research interests are the structure and function of the high mountain environment, and the stability of the natural environment of the mountains.

${ }^{1}$ Jagiellonian University, Institute of Geography and Spatial Management, Gronostajowa 7, 30-387 Cracow, Poland

${ }^{2}$ University of Natural Resources and Life Sciences (BOKU), Institute of Landscape Development, Recreation and Conservation Planning, Peter-JordanStraße 82, 1190 Vienna, Austria

${ }^{3}$ Tatra National Park, Zakopane, Kuźnice 1, 34-500 Zakopane, Poland 